UDC 656. 338. 12

JEL: F15, R 41, K23

\section{Vitaly Gurnak}

Doctor of Economic Sciences, Associate Professor

National Transport University,

Kyiv, Ukraine,

E-mail: tpsalkaf@ntu.edu.ua

orcid.org/0000-0001-5029-4818

\section{Inna Khomenko}

Doctor of Economic Sciences, Associate Professor

Chernihiv National University of

Technology,

Chernihiv, Ukraine

E-mail: innakhomenko28@gmail.com orcid.org/0000-0002-0839-4636

\section{Lyudmila Volynets}

Candidate of Economic Sciences,

Associate Professor,

National Transport University,

Kyiv, Ukraine

E-mail: Volinec_3@ukr.net

orcid.org/0000-0002-5064-2349

Received: February, 2018

Accepted: March, 2018

(C) Economics. Ecology. Socium, 2018

CC BY-NC 4.0 license

\section{IMPERATIVES OF MULTIMODAL TRANSPORT DEVELOPMENT IN ACCORDANCE WITH THE TENDENCIES OF THE TRANSFORMATIONAL CHANGES OF THE NATIONAL ECONOMY IN THE CONDITIONS OF EUROPEAN INTEGRATION}

Introduction Despite the existing potential of freight capacity of rail, sea and river transport, their interaction is still in need of improvement. Given the high growth rates of international container traffic, Ukraine's transport infrastructure requires immediate modernization and investment in the technical and economic condition in a context of intense competition with foreign transport companies and ports.

Aim and tasks is to identify and substantiate the possibilities of improving the mechanism of organization of multimodal transportation in accordance with the latest trends and ensuring the further sustainable development of multimodal cargo transportation, etc.

Research results. It established that at the present stage, multimodal transport covers not only technological aspects of coordinated work of different types of transport, but also concerns economic, organizational and legal provision of transport process, efficient functioning of transport infrastructure, optimal use of vehicles and cargo units during traffic flow. The article investigates the theoretical basis of multimodal transport, defines the general principles of the multimodal transportation system functioning, raises the grounds for the possible development of multimodal transport and improvement of the transport industry in Ukraine, as well as increasing the competitiveness of domestic enterprises. The methodical provisions of multimodal transport development in Ukraine offered.

Conclusion. Today it is necessary to introduce new principles of formation and coordination of state policy in the field of transport, creation of conditions for ensuring control over the quality of performance of the functions of the relevant executive authorities.

Organization of multimodal transport, which will be carried out by a single operator on a single transport document and through a freight rate, will increase the quality of transport and logistic services, will ensure a high level of reliability and security of international freight delivery chains.

Keywords: multimodal transportation, transport infrastructure, interaction of modes of transport, transportation, international freight transportation, development. 
УДК 656. 338. 12

JEL: F15, R 41, K23

\section{Віталій Гурнак}

Доктор економічних наук, професор,

Національний транспортний

університет,

Київ, Україна,

E-mail: tpsalkaf@ntu.edu.ua

orcid.org/0000-0001-5029-4818

\section{Інна Хоменко}

Доктор економічних наук, доцент, Чернігівський національний технологічний університет, Чернігів, Україна, E-mail: innakhomenko28@gmail.com orcid.org/0000-0002-0839-4636

\section{Людмила Волинець}

Кандидат економічних наук, доцент,

Національний транспортний університет, м. Київ, Україна

E-mail: Volinec_3@ukr.net orcid.org/0000-0002-5064-2349

Отримано: Лютий, 2018

Прийнято: Березень, 2018

(C) Економіка. Екологія. Соціум, 2017

CC BY-NC 4.0ліцензія

\section{ІМПЕРАТИВИ РОЗВИТКУ МУЛЬТИМОДАЛЬНИХ ПЕРЕВЕЗЕНЬ У ВІДПОВІДНОСТІ 3 ТЕНДЕНЦІЯМИ ТРАНСФОРМАЦИЙНИХ ЗРУШЕНЬ НАЦІОНАЛЬНОГО ГОСПОДАРСТВА В УМОВАХ СВРОІНТЕГРАЦЇ̈}

Проблема. Не дивлячись на існуючий потенціал провізної здатності залізничного, морського і річкового транспорту, їх взаємодія поки що потребує вдосконалення. Враховуючи високі темпи зростання міжнародних контейнерних перевезень, транспортна інфраструктура України потребує негайної модернізації та інвестування техніко-економічного стану в умовах гострої конкурентної боротьби із зарубіжними транспортними компаніями і портами.

Мета та завдання. Метою статті $\epsilon$ виявлення та обгрунтування можливостей удосконалення організації мультимодальних перевезень у відповідності 3 новітніми тенденціями та забезпечення подальшого сталого розвитку мультимодальних перевезень вантажів, тощо.

Результати. Встановлено, що на сучасному етапі, мультимодальні перевезення охоплюють не лише технологічні аспекти узгодженої роботи різних видів транспорту, а також стосуються економічного та організаційно-правового забезпечення перевізного процесу, ефективного функціонування транспортної інфраструктури, оптимального використання транспортних засобів та вантажних одиниць під час руху вантажопотоків. В статті досліджено теоретичні основи мультимодальних перевезень, визначенні загальні принципи функціонування мультимодальної системи перевезення, проведено обгрунтування заходів, щодо можливого розвитку мультимодальних перевезень та покращення транспортної галузі в Україні, а також підвищення конкурентоспроможності вітчизняних підприємств. Запропоновано методичні положення розвитку мультимодальних перевезень в Україні.

Висновки. На сьогодні $є$ необхідним впровадження нових принципів формування та координації державної політики в галузі транспорту, створення умов забезпечення контролю за якістю виконання функцій відповідних органів виконавчої влади. Організація мультимодальних перевезень, яка здійснюватиметься одним оператором за єдиним транспортним документом та наскрізною ставкою фрахту сприятиме підвищенню якості транспортно-логістичного обслуговування, забезпечить високий рівень надійності та безпеки міжнародних ланцюгів доставки вантажів.

Ключові слова: мультимодальні перевезення, транспортна інфраструктура, взаємодія видів транспорту, транспортування, міжнародні вантажні перевезення, розвиток. 
Introduction. Interaction of different types of transport in international cargo traffic is today one of the most demanded and actual types of services. Having a convenient network of roads allows you to carry cargo in all directions, not only within the continent, but also through rail and sea transport and ferries to other countries and continents.

At present, the role of international transportation needs special attention and development. International cargo transportation is the transportation of goods between several countries, the feature of which is the mandatory crossing of the border of at least two adjacent countries [1].

Multimodal cargo transportation is one of the most important constituents of the transport concept of world and national importance, which promotes efficient interaction of competing enterprises of different types of transport while providing high-quality services of modern format. Such transportation provides "door to door" and "on time" delivery, as well as a number of benefits in terms of cost optimization, an efficient system for controlling cargo handling, simplifying numerical procedures at different parts of the logistics supply chain, which helps to increase the economic level of enterprises multimodal transportation.

Particularly topical significance is the multimodal transportation in the context of realization of the potential of European integration, simplification of trade and logistics procedures, development of international partnership. Thus, in the presence of negative macroeconomic tendencies, foreign trade operations conducted today with partners from 220 countries of the world, and the largest volumes of exports among services accounted for transport services, which occupied $54.8 \%$ of the total volume of exports.

The period after the start of hostilities in the Donbass and the accession of the Crimea to the Russian Federation has a very significant negative impact on the functioning of various modes of transport in Ukraine. In fact, rail and road transport work under the Russian embargo. Ukrainian manufacturers and transporters forced to seek new ways of transporting their goods bypassing Russian sanctions. This objectively requires a change in the priorities of infrastructure development for railways and seaports, through which domestic traffic flows.

It is clear that the work of the transport complex is a reflection of the state of the economy of the country, which is now not in the best condition.

Analysis of recent research. Foreign experience confirms that in the sphere of transport one of the main factors of increasing the level of economic development of multimodal transport and guaranteeing its sustainability. It is worth highlighting also the works of T. Brands, E. Berkum, M. Blimer, L. Wismans, D. Johnson, S. Hamadi, M. Xoory, H. Yasukawa, I. Chen, A. Paulrey and others. researchers emphasizing the important role and importance of multimodal transport.

Strengthening of positions in the domestic transport market with the introduction of modern security mechanisms of logistics and multimodal transportation in the conditions of the formation of a favorable economic environment is researched in the works of domestic scientists, in particular: M.F. Dmitrichenko [1], O. Y. Sokolova [3], O.V. Yavtseva [4], L.M. Volynets [6], V.V. Koval [10], S.M. Shkarlet [13] and others.

\section{Previously unsettled problem}

constituent. The overall problem of creating an efficient transport network has led to the development of all types of transportation of Ukraine, as well as an increase in the role of international freight transport, which became the main task of most scientists and scientists in this direction. However, despite the substantial amount of work in this direction, there remain issues that need further improvement.

Particular attention paid to the problems of the formation of optimal modes of delivery of cargoes under the conditions of interaction of different types of transport, in particular, with the use of modern concepts of intermodal multimodal transport. However, taking into account a considerable number of scientific developments, scientists have not yet developed a common view on the interpretation and content of the concept of "multimodal 
transport", besides, the problems of organization and development of multimodal transport in Ukraine are somewhat fragmented and therefore are relevant and require detailed research.Indeed, to date, research by researchers reflects mainly the technical and technological aspects of multimodal transport, while the economic issues of transport companies in multimodal transport of goods remain poorly researched.

Paying attention to economic and political instability in Ukraine, as well as insufficient financing of the industry, the economic issues of organizing multimodal transport in accordance with the latest trends in the reform of transport sector enterprises, improving tariff regulation, and assessing the efficiency, ensuring the further sustainable development of multimodal transport of goods, etc.

Aim and tasks. The aim of the article is to identify and substantiate the possibilities of improving the mechanism of organization of multimodal transportation in accordance with the latest trends and ensuring the further sustainable development of multimodal cargo transportation, etc.

Main results. The current economic situation requires the search for new approaches to simplify the procedures for trade in goods, among which the main place is the procedures for moving goods between the seller and the buyer. And in this sense, multimodal transportation of goods is aimed at eliminating technical, organizational, and other barriers during the movement of goods by the links of the supply chain.

The development of multimodal transportation is a promising direction for the development of the transport system of Ukraine, as it can significantly increase the volume of transportation by its territory with the participation of national transport companies, contributing to increasing the competitiveness of the country in the world transport services market, developing a network of existing transport corridors, integrating Ukraine's transport infrastructure with the world transport systems. For the development of effective directions for the development of multimodal transport in Ukraine, an important task is to conduct a scientific study of the conceptual apparatus of multimodal transport and related existing conceptual provisions.

After all, the interest of international cooperation in resolving issues related to international transport activities for the provision of mixed (multimodal) freight services was determined at the end of the nineteenth century, when the Berne International Convention on the Carriage of Goods by Rail was signed in 1890, which provided for a special form a consignment note for which a mixed shipping of goods could be made.

At the same time, the first half of the twentieth century, was not sufficiently productive and successful for the international unification of the rules governing mixed freight, since in 1927 only the Stockholm Conference of the International Chamber of Commerce held, where the question raised about the need to unify such transport.

1969 At the Tokyo Conference of the International Maritime Committee, a draft international convention on mixed transport, or Tokyo Rules, developed. The ideas of the Tokyo Rules are the basis of the forms of transport documents developed for the clearance of mixed freight by international organizations such as FIATA, BIMKO.

In 1973 The International Chamber of Commerce has developed the International Rules for Mixed Transport, which are also based on the Tokyo Rules. In 1980, the UN Convention on International Multimodal Transport of Goods signed in Geneva.

It noted that so far in the scientific literature there is a discussion about the conceptual apparatus of mixed cargo transportation. The phrase "international combined transport of goods" is the official equivalent of the English word, which is part of the UN Convention on International Multimodal Transport of Goods, developed under the auspices of UNCTAD and adopted by consensus on May 24, 1980 at the Conference of the United Nations full representatives. That is, the key definition of "multimodal" is the term "mixed". 
The term "intermodal transportation" used in the modern Terminology of Mixed Transport, which has been prepared for the work of three intergovernmental organizations the European Union (EU), the European Convention of the Ministries of Transport (ECMT) and the Committee on Inland Transport of the UN Economic Commission for Europe (UNECE).

Intermodal transport - is the consistent movement of goods by two or more modes of transport in the same cargo unit or in a vehicle without overloading the load when changing the mode of transport (without loading and unloading operations).
In the terminology of combined transport, the systematization of transportation and allocation of multimodal or mixed transport as a co-ordinated terminal carried out.

Under intermodal transport, combined transport meant, while car-rail, water, rail, water and road transport [Nikiforuk] act as a combination of combined transport. At the same time, Ukrainian scientists attempted to develop a modern classification of mixed types of transportation. The description of the essence of these and other types of mixed transport is given (Table 1) [4].

\section{Table 1. Major types of mixed traffic and their characteristics}

\begin{tabular}{|c|l|}
\hline Means of transportation & \multicolumn{1}{c|}{ Characteristics of transportation methods } \\
\hline Unimodal transportation & $\begin{array}{l}\text { Performed by one mode of transport by one or more carriers. If only one carrier is } \\
\text { involved in the carriage, he issues his own transport document, such as a bill of } \\
\text { lading, a transport bill, etc. }\end{array}$ \\
\hline Intermodal transportation & $\begin{array}{l}\text { There are several types of transport. In this case, one of the carriers organizes all } \\
\text { transportation from the point of departure to the destination through all } \\
\text { intermediate points. Documents for carriage are issued depending on the } \\
\text { distribution of responsibility for the carriage. }\end{array}$ \\
\hline Multimodal transportation & $\begin{array}{l}\text { Performed by different modes of transport, which belong to the same legal entity, } \\
\text { or it manages them. The operator organizing the carriage takes responsibility for } \\
\text { all transportation. It is he who issues a multimodal document. }\end{array}$ \\
\hline Segmented transportation & $\begin{array}{l}\text { The carrier, which organizes the carriage, assumes responsibility only for its part } \\
\text { of the work. He may write a document for intermodal or combined transportation. }\end{array}$ \\
\hline Combined transportation & $\begin{array}{l}\text { There are more than two modes of transport. Implemented by the carriage of } \\
\text { goods in the same container or vehicle in successive different types of transport. } \\
\text { Used through document }\end{array}$ \\
\hline
\end{tabular}

Source: based on the data [4]

Therefore, based on the foregoing, multimodal transport interpreted as an international carriage performed by two or more modes of transport, organized by an operator, which assumes the responsibility of delivering cargo "from door to door" under a single contract and through the freight rate.

Multimodal transport is more complex and comprehensive than transportation by different modes of transport. At the same time, they are more simple for the clients, because unlike the situation when importers, exporters and cargo owners turn to several carriers companies, draw up several transport documents, pay their services under different tariff schemes, etc. The client deals only with the multimodal transportation system with the operator of the company, which assumes the responsibility for the quality delivery of the goods.

It is important to emphasize that it is precisely the presence of a multimodal carrier that is responsible for the load and the possible risks associated with delivery throughout the track regardless of the number of modes of transport involved in the delivery process. When issuing a single transport document is the main distinguishing feature from all other related transport concepts.

It can be noted that there are five signs of multimodal traffic: the involvement of at least two modes of transport (1); responsible for transportation - multimodal transportation (2); documentary combination of different types of 
transport at the expense of a single transport document (3); the operator applies a single, cross-rate tariff rate for the entire route of transportation (4); the cargo on the entire multimodal route is in the same transport unit (5).

Taking into account the complexity of multimodal transport, enterprises acting as operators and assuming legal and financial responsibility for the quality of LT (just-intime) delivery should be leaders in the transport services market, have a reputable reputation, partner trust, keep a team of experienced professionals, use high-quality productive resources. Multimodal transport is often justified as cargo integration, network integrators [8], since they act as service providers, delivery organizers when combining the most advantageous from the point of view of quality and efficiency of carriers, routes, forms of delivery, etc.

The transport process in multimodal transportation consists of several successive stages of delivery and overload of cargo from one mode of transport to another with their inclusion in the general system of transportation.

That is why multimodal transport needs to be considered from the point of view of the system approach as complex systems, which are characterized by integrated development of all types of transport, terminal and warehouse facilities, customs and financial infrastructures, regulatory and information technologies, information and telecommunication support of freight traffic. The presence of a multimodal transport operator can ensure the integrity and unity of the system.

Based on world experience, it can be stated that multimodal transportation is a modern way of delivering goods, based on logistic principles and concepts, which is an essential condition for the development of foreign trade relations of the present. The prospects and advantages of the existence of such a method of transportation of goods do not call doubt. Thus, among the main advantages of multimodal transport, the following should be noted:

1) the possibility of delivery of goods according to the logistic principle "from door to door" at optimal cost (provides the choice of optimal cargo delivery scheme, route flexibility, etc.);

2) the possibility of using different types of containers depending on the dimensions, chemical and technical features of the cargo (containerization is an integral part of the process of delivery of cargo by multimodal transport);

3) coordinated and coordinated work of various elements of the transport infrastructure (it allows to optimize the total cost of the whole scheme of delivery of goods);

4) organization of transportation by one company - the operator of transport services (shortening of time for the coordination of various organizational, legal and technical issues, increase of the level of safety of transportation and storage of cargo).

Ensuring the efficient operation and optimal development of the multimodal transport system requires the implementation of a number of principles, the most common of which being: a single commercial law field; complexity of decision of financial and economic aspects of system functioning; information provision of all parts of the transportation process; organizational and technological interaction, coordination and synchronization of the work of all parts of the transportation process; cooperation of all participants of the multimodal transportation system; Integrated infrastructure development of various modes of transport. Characteristics of the multimodal transport system's general principles of operation are given in table. 2 
Table 2. Principles of multimodal transport system operation

\begin{tabular}{|c|c|}
\hline Principles & Substantive provisions \\
\hline $\begin{array}{l}\text { The only commercial } \\
\text { legal field }\end{array}$ & $\begin{array}{l}\text { Improvement of the rules of transportation of goods in international traffic on all types } \\
\text { of transport in order to share them, depending on the chosen criterion of efficiency of } \\
\text { the multimodal system functioning in the current conditions of foreign trade relations; } \\
\text { simplification of customs formalities and procedures; development and implementation } \\
\text { of unified transport documents of international standard for work on both internal and } \\
\text { external market of transport-logistic services, etc. }\end{array}$ \\
\hline $\begin{array}{l}\text { Complexity of decision } \\
\text { of financial and } \\
\text { economic aspects of } \\
\text { system functioning }\end{array}$ & $\begin{array}{l}\text { Development and establishment of unified tariff rules for the transit of international and } \\
\text { foreign cargo in international traffic; development of the method of optimal distribution } \\
\text { of through freight between all links in the chain of cargo delivery; development and } \\
\text { introduction of a mechanism of financial responsibility for violation of quality of } \\
\text { services, etc. }\end{array}$ \\
\hline $\begin{array}{l}\text { Information provision } \\
\text { of all parts of the } \\
\text { transportation process }\end{array}$ & $\begin{array}{l}\text { Informatization is a prerequisite for the operation of a multimodal cargo transportation } \\
\text { system, which ensures the planning, management, monitoring and control of cargo } \\
\text { movement at all stages of the door-to-door delivery chain }\end{array}$ \\
\hline $\begin{array}{l}\text { Organizational and } \\
\text { technological } \\
\text { interaction, } \\
\text { coordination and } \\
\text { synchronization of the } \\
\text { work of all stages of } \\
\text { the transportation } \\
\text { process }\end{array}$ & $\begin{array}{l}\text { The effectiveness of a multimodal system depends heavily on its organization. The } \\
\text { guarantor and organizer of the coordinated, coordinated and synchronized operation of } \\
\text { all parts of the cargo delivery process is the multimodal transportation operator. The } \\
\text { Multimodal Transport Operator organizes the delivery of the cargo on a single transport } \\
\text { document, which ensures an appropriate level of quality of service, safety of } \\
\text { transportation and safety of the cargo at a single cross-check freight rate. }\end{array}$ \\
\hline $\begin{array}{l}\text { Co-operation of all } \\
\text { participants of } \\
\text { multimodal } \\
\text { transportation system }\end{array}$ & $\begin{array}{l}\text { Cooperation involves co-operation of several economic entities on the basis of } \\
\text { voluntary contractual relations with the aim of increasing overall competitiveness. } \\
\text { Formation of relations on the conditions of cooperation allows: to increase the } \\
\text { competitiveness of individual parts of the chain of delivery of cargo at the expense of } \\
\text { mutual support of other participants in the transportation process and reduce the system- } \\
\text { wide costs for the provision of transport-logistics services; increase the image of the } \\
\text { participants in the transportation process; formation of flexible tariff policy; } \\
\text { achievement of synergistic effect of multimodal transportation system, etc. }\end{array}$ \\
\hline $\begin{array}{l}\text { Complex development } \\
\text { of infrastructure of } \\
\text { different types of } \\
\text { transport }\end{array}$ & $\begin{array}{l}\text { The possibility of using advanced technologies in the transportation process is } \\
\text { determined by the level of development of transport infrastructure, which can be } \\
\text { divided into two main elements - terminal complexes and transport routes. The } \\
\text { effectiveness of the multimodal transportation system and the very ability to operate it } \\
\text { (due to different capacity of freight traffic and delivery speed) depends on the } \\
\text { availability of space in the transport system and the functions of the terminals that } \\
\text { provide handling of freight flows. Comprehensive development of transport } \\
\text { infrastructure is based on the standardization of kits of cargoes (containers), vehicles, } \\
\text { loading and unloading machines and mechanisms, etc. }\end{array}$ \\
\hline
\end{tabular}

Source: composed on the data [1].

The highly developed transport system of each state is a guarantee of its economic growth and well-being of its citizens, as the country's economic development closely linked with the development of communication routes.

Expansion of demand for transportation by all types of transport in world markets accompanied by higher requirements for the quality of transport services. On this basis, at the Crete European Community Conference, held in 1994, the beginning of the formation of international transport corridors initiated.

In general, the international transport corridor is a complex of land and waterways with appropriate infrastructure in a certain direction, including auxiliary structures, access roads, border crossings, service points, cargo and passenger terminals, equipment and equipment for traffic management, organizational and technical measures, legislative and regulatory acts. That ensure the carriage of goods and passengers at a level meeting the requirements of the European Community.

Currently, three Pan-European "Cretan" transport corridors (3rd, 5th and 9th) and four corridors of the Railways Cooperation 
Organization (3rd, 5th, 8th and 9th) pass through the territory of Ukraine.

The development of these corridors, bringing them to international norms and standards is the main direction of the state policy of entering the national transport system into an international one.

It is worth mentioning that during the implementation of measures on the elimination of bottlenecks and the development of rail transport, a two-track Beskid Tunnel constructed. Upon completion of the construction, the capacity of the tunnel will increase to 100 pairs of trains per day, and their speed will increase to $70 \mathrm{~km} / \mathrm{h}$. It is worth noting that the Beskydy tunnel is the first significant element of the transit transport infrastructure of Ukraine, created during the years of independence with the attraction of foreign financial resources.

At the same time, based on the current political realities, there is a high probability of impossibility of its full use. If we analyze the "Transport Corridor Scheme", then it is clear that all of them go to the territory of Russia or to non-controlling Ukraine part of Donetsk and Luhansk Oblasts.

Perhaps even at the expense of the State Budget of Ukraine it is expedient to find funds for the participation of PJSC "Ukrzaliznytsya" in the international project "Britshpur Planningggesellschaft mbh", which involves the construction of the railroad 1520 and the infrastructure of direct rail link Chop-KosiceBratislava-Vienna. In the future, this will be very important for cooperation within the framework of the project "New Silk Road" and attracting significant volumes of transit cargo in the East-West direction. This is why it is very important to use more intensively the direction of transportation to the EU countries of the western border crossing. However, there is still insufficiently developed logistics infrastructure, and the situation requires an immediate solution.

Using the interaction of different types of transport can significantly reduce the financial costs of transporting certain types of goods. Thanks to multimodal transportation, the enterprises of the country will be able to expand the first-class range of services they offer. The use of multimodal transportation for Ukrainian enterprises can carried out in several directions. The first of these is the combination of road transport and rail.

One of the most advantageous options for interoperability with rail transport is the use of crossing of railways and highways in the Lviv region, which will allow the use of the TransEuropean transport network for transportation with countries of Europe and the CIS.

The main ways of communication and the country in which you can use the intersection of automobile and railways are given in (Table 3 ) [4].

Table 3. Ways of communication with CIS countries

\begin{tabular}{|c|c|c|}
\hline Country & Roads by Road Transport & Connections by Rail \\
\hline Poland & Krakovets, Rava-Ruska, Yagodin & Yagodin, Mostyska II \\
\hline Romania & Dyako, Porubne & Dyako, Vadul Ciret \\
\hline Slovakia & Uzhhorod & Chop \\
\hline Hungary & Tisza & Chop / Batovo \\
\hline
\end{tabular}

Source: composed on the data [4].

Taking into account the general tendency of Ukraine's rapprochement with Western Europe, in the future, the rapid growth of trade with the European Union, as well as the increase in demand for passenger transportation through the introduction of a visa-free regime, railwaymen should take care of closer transport links with Poland. Therefore, a very relevant project is the electrification of the KovelVolodymyr-Volynsky-Izov section of the regional branch "Lvivska zaliznitsa" (operating length - $74.7 \mathrm{~km}$ ). Its implementation will 
allow to increase the efficiency and speed of cargo transportation to the LHS line $(1520 \mathrm{~mm}$ wide-gauge branch in Poland $400 \mathrm{~km}$ from the border to Slavkovo).

Another promising direction for road and rail cooperation in the future is China-initiated construction of a high-speed rail link from Europe to China, which takes the route London - Paris - Berlin - Warsaw - Kiev - St. Petersburg - Moscow - Yekaterinburg - Astana - Irkutsk - UlanBator - Beijing. Growth in trade between Ukraine and the EU, as well as between the EU and China, Russia and India, has led to the initiative to build this highway, and can enable Ukrainian transport companies to offer customers a profitable way to combine transportation.

The second direction of the use of multimodal transportation is the combined car and sea transportation. This area focused on the use of possible multimodal terminals of Ukrainian seaports.

In our opinion, sea transport should be the subject of increased attention from the authorities. In the southern regions of our state, the most important enterprises of the maritime and railway infrastructure are concentrated, which is the basis for conducting now foreign economic activity. Moreover, Crimea is temporarily in someone else's hands, and Azov is actually a zone of hostilities. The fact that the Kerch Strait is now actually subordinated to the Russian authorities not be rejected, which is why it requires significant investments here. In particular, the region plays a key role in the development of freight transport and logistics and the growth of the potential of intermodal transport [1].

It is worth mentioning the prospects of cooperation with the Illichivsk Sea Commercial Port. The advantage of carrying out overloads in this port is justified by the following reasons:

1. The port has the state-of-the-art multimodal terminal specializing in servicing rail-ferry and car-ferry lines.

2. The capacities of the terminal of the port ensure the functioning of the Euro-Asian transport corridor connecting the countries of Western Europe, Ukraine, Georgia and the countries of Asia, which will allow the enterprise to cooperate in the Asian direction.
3. The terminal has independent entrances for vehicles.

4. The capacity of the terminal allows you to overload 10 thousand heavy vehicles and 250 thousand units of wheeled equipment per year.

5. Proximity to the main transport artery of the country - the highway Kiev-Odessa will allow to deliver cargo efficiently.

Due to the global crisis and the unstable political situation in Ukraine, the prospects for the active implementation of road and sea transport are not large enough, since not all Ukrainian ports have the ability to implement multimodal terminals. But looking at these characteristics, we can say that in Ukraine there is already a normative and functional basis for improving the mechanism of combined road and sea transport, which is one of the main stages of improving the transport and logistics system of the country.

Positive changes in the economic and political situation of the country will further enable the formation of multimodal terminals at other sea ports, where they have not yet been introduced, will ensure the servicing of new lines of transportation, will reduce the time of delivery of goods, and significantly reduce the financial costs of transportation. For example, the Odessa Sea Port, together with EvroTerminal, is planning a joint dry port project, which involves the creation of a single multimodal logistics center.

The development of multimodal transport in any country based on the interaction of the three key partners that take an active part in the process of transporting goods in mixed traffic [5]:

1) a state which develops and implements national legal acts concerning international trade and transportation;

2) service providers, including suppliers of transport and logistics services (carriers, forwarders, multimodal carriers, etc.) who perform multimodal transport operations in accordance with national and international trade and transport practices;

3) suppliers of related services taking part in foreign economic relations (banking institutions, leasing and insurance companies, etc.). 
The activities of the above-mentioned participants cover not only the organizationaleconomic, commercial or technological aspects of international transportation, but also all the issues concerning the simplification of trade procedures and liability for the transported cargo, that is, they contribute to the development of a multimodal freight transport system.

Characteristics of the main directions of activity of participants in the transportation process in relation to the development of multimodal transportation given in table. 4

\section{Table 4. Main directions of activities of participants in the transport process for the} development of multimodal transport

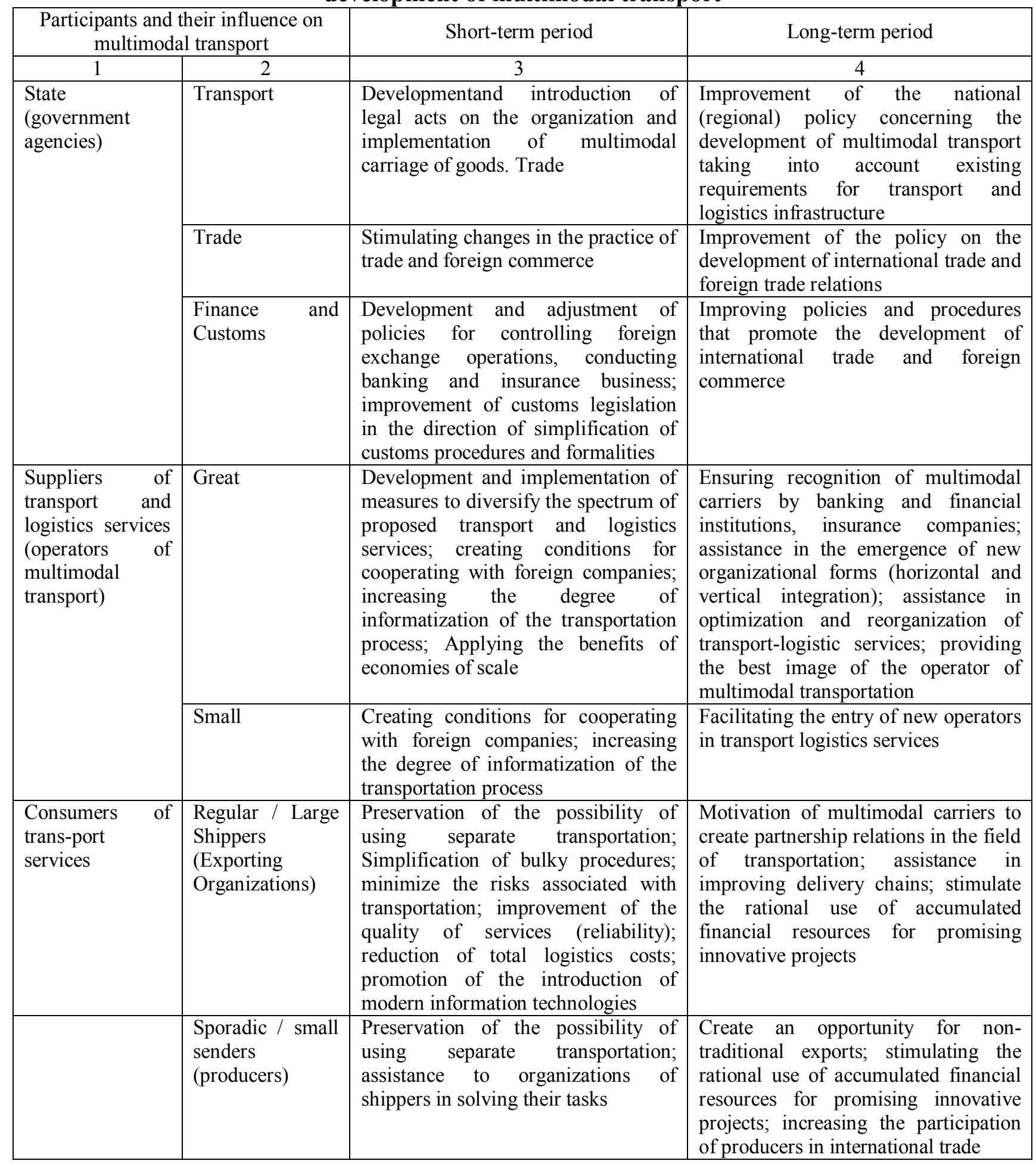

Source: composed on the data [3]. 
It is important to emphasize that the activities of partner partners in the multimodal transportation of cargoes is not limited only by the influence of each of them on the process of transportation, but also provides for the implementation of certain measures in relation to each other on the development of international trade and transport. Typical directions of interaction of partner-participants in multi-modal transportation are presented in the table. 5

\section{Table 5. Typical directions of interaction of partner participants in multimodal transportation}

\begin{tabular}{|c|c|c|c|}
\hline $\begin{array}{l}\text { Participants of } \\
\text { the multimodal } \\
\text { transport } \\
\text { partners }\end{array}$ & State & $\begin{array}{c}\text { Providers of transport and logistics } \\
\text { services }\end{array}$ & $\begin{array}{c}\text { Consumers of transport-logistics } \\
\text { services }\end{array}$ \\
\hline State & $\begin{array}{l}\text { - simplification of } \\
\text { customs procedures and } \\
\text { formalities; } \\
\text { liberalization of control } \\
\text { over currency } \\
\text { operations, etc. }\end{array}$ & $\begin{array}{l}\text { - provision of transport infrastructure; } \\
\text { - introduction of legal requirements } \\
\text { (licenses); - adoption of a system of } \\
\text { financial collateral for the } \\
\text { implementation of the agreement; - } \\
\text { liberalization of services, etc. }\end{array}$ & $\begin{array}{l}\text { - development and } \\
\text { implementation of an export } \\
\text { expansion strategy; - development } \\
\text { and implementation of import } \\
\text { substitution strategy; } \\
\text { introduction of an effective } \\
\text { system of customs clearing and } \\
\text { storage of goods, etc. }\end{array}$ \\
\hline $\begin{array}{l}\text { Providers of } \\
\text { transport and } \\
\text { logistics } \\
\text { services }\end{array}$ & $\begin{array}{l}\text { - Lobbying / putting } \\
\text { pressure on the } \\
\text { development } r \text { and } \\
\text { implementation of } \\
\text { necessary regulatory } \\
\text { acts }\end{array}$ & $\begin{array}{l}\text { - ensuring the growth of competence } \\
\text { and professionalism of profile } \\
\text { organizations; - search and realization } \\
\text { of effective methods of logistic } \\
\text { management of the system of } \\
\text { transport-logistic services; - } \\
\text { introduction in of the transportation } \\
\text { technologies in the } \\
\text { process, etc. }\end{array}$ & $\begin{array}{l}\text { - marketing of transport logistics } \\
\text { and tradeeconomic services; - } \\
\text { establishment of stable relations } \\
\text { with potential clients; - } \\
\text { assessment of the requirements of } \\
\text { consumers and the creation of } \\
\text { conditions for their satisfaction, } \\
\text { etc. }\end{array}$ \\
\hline $\begin{array}{l}\text { Consumers of } \\
\text { transport- } \\
\text { logistics } \\
\text { services }\end{array}$ & $\begin{array}{l}\text { - Lobbying / putting } \\
\text { pressure on the } \\
\text { development } \\
\text { implementation and } \\
\text { necessary regulatory } \\
\text { acts }\end{array}$ & $\begin{array}{l}\text { - long-term partnership with the } \\
\text { selected supplier of transport and } \\
\text { logistics services; - raising the level of } \\
\text { informatization of technological } \\
\text { processes; - search for competitive } \\
\text { competitive offers, etc. }\end{array}$ & $\begin{array}{l}\text { - improvement of procedures for } \\
\text { the application of commercial } \\
\text { practices; - establishment of } \\
\text { stable partnerships with shippers; } \\
\text { - the best understanding of the } \\
\text { requirements for goods, etc. }\end{array}$ \\
\hline
\end{tabular}

Source: composed on the data [3].

Multimodal transportation of goods, as a rule, is carried out through international transport corridors, provides for the most tight integration, based on the unity, interaction and coordination of all units and participants in the delivery chain.

It is worthwhile to note that Ukraine occupies the 4th place in the world (after the USA, Russia, Canada) by the indicator of the operational length of public railway tracks. Ukraine's railway network in Europe is one of the most powerful, and in the 1990s it was ranked first in terms of cargo tension. Ukraine also has a developed infrastructure of rail and water transport. Through the Ukraine, there are international transport corridors, in particular: pan-European transport corridors No. 3, 5, 7, 9, corridors of the Organization of Cooperation of Railways No. 3, 4, 5, 7, 8, 10 and the transport corridor Europe-Caucasus-Asia (TRACECA), which provides the connection of Western Europe through the Black Sea, the Caucasus and the Caspian Sea with Central Asia [3].

Consequently, the development of multimodal transportation determined by the existing demand for this type of services, the volume of orders, the range of goods, terms of delivery, consumer requirements, as well as delivery routes. It noted that at the present stage in Ukraine, such a way of organizing the delivery of goods is at an initial stage and its active development hampered by the presence of certain problems, the elimination of which involves the implementation of appropriate measures. The main problems and corresponding measures for their elimination given in the table. 6 . 


\section{Table 6. Main directions of multimodal transport development in Ukraine}

\begin{tabular}{|c|c|}
\hline Problem & Necessary measures \\
\hline $\begin{array}{l}\text { 1. Imperfection of the normative legal base of } \\
\text { mixed transport, in particular multimodal } \\
\text { transport, uncertainty of strategic directions of } \\
\text { their development }\end{array}$ & $\begin{array}{l}\text { Develop and implement a consistent international regulatory framework } \\
\text { for the legitimization of multimodal transport, which will identify the } \\
\text { different modes of transport, the responsibility of the parties, the } \\
\text { functions of multimodal transport operators and requirements for } \\
\text { documentation [8] }\end{array}$ \\
\hline $\begin{array}{l}\text { 2. Disparities between levels of development } \\
\text { of infrastructure of different types of } \\
\text { transport, hindering the development of } \\
\text { container and piggyback transportations }\end{array}$ & $\begin{array}{l}\text { Formation of effective transport policy of the state (region) is aimed at } \\
\text { the uniform development of various types of transport, optimal } \\
\text { distribution of freight flows between them, ensuring their organizational } \\
\text { and technological interaction and system functioning }\end{array}$ \\
\hline $\begin{array}{l}\text { 3. High risks of multimodal carriers in the } \\
\text { organization of door-to-door cargo delivery }\end{array}$ & $\begin{array}{l}\text { Development and implementation of an effective risk management } \\
\text { system, the introduction of integrated risk management mechanisms that } \\
\text { arise during the organization, as well as multimodal transport operations. }\end{array}$ \\
\hline $\begin{array}{l}\text { 4. Lack of a developed network of objects of } \\
\text { transport and logistics infrastructure }\end{array}$ & $\begin{array}{l}\text { Formation of optimal transport and logistic infrastructure both at the } \\
\text { regional and at the state level; formation of an effective system of } \\
\text { transport-logistics system management }\end{array}$ \\
\hline $\begin{array}{l}\text { 5. The absence of a representative network of } \\
\text { national operators of transport and logistics } \\
\text { services abroad, which would ensure a high } \\
\text { degree of coherence of the actions of all } \\
\text { participants in the transportation process and } \\
\text { protect the interests of the state abroad }\end{array}$ & $\begin{array}{l}\text { Stimulation and support of national operators of transport and logistics } \\
\text { services, conclusion of multilateral agreements and development of } \\
\text { partnership relations between Ukraine and foreign states, as well as } \\
\text { formation of a common policy in the field of transport and trade; } \\
\text { consolidation of competitive positions of national operators of transport } \\
\text { and logistics services in the international space }\end{array}$ \\
\hline $\begin{array}{l}\text { 6. Lack of competitive pricing policy in the } \\
\text { field of mixed and multimodal traffic }\end{array}$ & $\begin{array}{l}\text { Development of competitive pricing policy in the field of transport; } \\
\text { minimization and elimination of all unauthorized charges for transit } \\
\text { cargoes; development of the method and mechanisms of optimal } \\
\text { distribution of through freight between all links of the cargo delivery chain }\end{array}$ \\
\hline $\begin{array}{l}\text { 7. Lack of professional personnel and } \\
\text { specialists in the field of multimodal } \\
\text { transportation }\end{array}$ & $\begin{array}{l}\text { Formation of an effective system of training and retraining of specialists } \\
\text { in the field of transport both within the state and in the leading European } \\
\text { countries; organization of cooperation with international transport } \\
\text { organizations in order to obtain professional experience }\end{array}$ \\
\hline
\end{tabular}

Source: composed on the data [3]

Addressing the problems of developing multimodal transport in Ukraine based on the implementation of the above measures, will enable the creation of a strong and competitive transport and logistics sector of the country, will ensure its attractiveness not only at the domestic but also international level, as well as increase the volume of transit cargo, the formation of stable partners relations in the field of transport and logistics business, and will provide an opportunity to open additional sources of income both for the transport industry and for the state budget jet in general.

Conclusions and further research. As a result of the conducted research, it has been established that the formation of separate enterprises with different kinds of transport services in the single mechanism of multimodal transportation in accordance with the newest tendencies is a big problem, as well as the main task for our country. After all, recently the mechanism of organization of multimodal transport and its improvement is one of the main parts of the modern world, in the transport sector, which contributes to the stable development of the economy.

It substantiated that the development of multimodal transport in Ukraine is a promising direction for the formation of an efficient transport and logistic system of the country. Multimodal transportation is a modern concept of cargo transportation according to the logistic principle "from door to door".

It proved that today it is necessary to introduce new principles of formation and coordination of state policy in the field of transport, creation of conditions for ensuring control over the quality of performance of the functions of the relevant executive authorities.

Organization of multimodal transport, which will be carried out by a single operator on a single transport document and through a freight rate, will increase the quality of transport and logistics services, will ensure a high level of reliability and security of international freight delivery chains. 


\section{REFERENCES}

1. Dmitrichenko, M.F. (2012). International transportations.Lviv. Polytechnic [in Ukrainian].

2. Support for the integration of Ukraine into the Trans-European Transport Network TENT. RC7 Intersectoral issues. Multimodal transport (2017). Final Report 7.1. Retrived from: http://www.expresstrans.net/gruzak.html [in Ukrainian].

3. Sokolova, O.E. (2014). Theoretical Foundations of Organization and Development of Multimodal Transport in Ukraine. Economic Space, 83, 91-103. [in Ukrainian].

4. Yavtseva, O.V. (2016). Improvement of the mechanism of transport-logistic service of international freight traffic Retrived from: http://dspace.uabs.edu.ua/ jspui / handle / 123456789/8753. [in Ukrainian].

5. Mechanisms of efficient use and development of the potential of the road transport complex in Ukraine (2014). Kyiv: NISS, 60 [in Ukrainian].

6. Volynets, L.M. (2018) Analysis and prospects of development of a licensing system in the field of international road transport. Chernihiv: CHIBIB MNTU named after Academician Yu Bugaya, 41-42.

7. United Nations Convention on International Combined Customs Goods (1980). Retrived from: http://ci.uz.gov.ua/org/un/conv80comb.html [in Ukrainian].

8. Convention for international multimodal cargo transportation (1980). Retrived from: https://treaties.un.org/doc/Treaties/1980/05/19800524\%2006-13\%20PM/Ch_XI_E_1.pdf.

9. Levikov, G.A. \& Tarabanko, V.V. (2008) Mixed transportation. State, problems, trends. Moscow: RosKonsult [in Russian].

10. Koval, V.V. \& Kotlubay, V.O. (2015) Institutional Principles of Strategic Management of the Development of the Transport Services Market in Ukraine. Global and national problems of the economy, 5, 161-164. - Retrived from: http://global-national.in.ua/archive/5-2015/05_2015.pdf [in Ukrainian].

11. Polenkova, M.V. (2017). Distribution of financial resources for federal road funds. Scientific bulletin of Polissia, 2(10), 111-117.

12. Khomenko, I.O. (2017). Current state and features of the financing of the road sector Scientific bulletin of Polissia, 4(12), 201-205.

13. Shkarlet, S.M. (2017). Actual problems of formation and financing of state road funds. Scientific bulletin of Polissia, 3(11), 16-20.

14. On the ways of development of multimodal (combined) transport in Ukraine (2011). Analytical note. Retrived from: http://www.niss.gov.ua/articles/599.

\section{ЛІТЕРАТУРА}

1. Дмитриченко М.Ф. Міжнародні перевезення. Львів: Вид-во Львів політехніка, 2012. 308 c.

2. Підтримка інтеграції України до Транс-Свропейської транспортної мережі ТЄМ-Т. PК7. Міжгалузеві питання. Мультимодальний транспорт. Заключний звіт 7.1., 2017. URL: http://www.expresstrans.net/gruzak.html.

3. Соколова О.С. Теоретичні основи організації та розвитку мультимодальних перевезень в Україні. Економічний простір, 2014. № 83. С. 91-103.

4. Явцева О.В. Вдосконалення механізму транспортно-логістичного обслуговування міжнародних вантажних перевезень, 2016. URL: http://dspace.uabs.edu.ua/ jspui/handle/123456789/8753.

5. Механізми ефективного використання та розвитку потенціалу транспортнодорожнього комплексу України. Київ: НІСД, 2014. С.60. 
6. Volynets L.M. Analysis and prospects of the development of a licensing system in the field of international road transport. Чернігів: ЧІІБІП МНТУ імені академіка Ю. Бугая, 2017. C.41-42.

7. Конвенция Организации Объединенных Наций о международных смешанных перевозках грузов, Женева, 24 мая 1980 г. URL: http://ci.uz.gov.ua/org/un/conv80comb.html.

8. Конвенція про міжнародні мультимодальні перевезення вантажів, 1980. URL: https://treaties.un.org/doc/Treaties/1980/05/19800524\%2006-13\%20PM/Ch_XI_E_1.pdf.

9. Левиков, Г.А. Тарабанько В.В. Смешанные перевозки. Состояние, проблемы, тенденции. М.: РосКонсульт, 2008. 320 с.

10. Коваль В.В., Котлубай В.О. Інституціональні засади стратегічного управління розвитком ринку транспортних послуг в Україні. Глобальні та національні проблеми економіки. 2015. №5. C. 161-164. URL: http://global-national.in.ua/archive/5-2015/05_2015.pdf.

11. Polenkova M.V. Distribution of financial resources for federal road funds. Scientific bulletin of Polissia. 2017. № 2 (10). P. 111-117.

12. Khomenko, I. O. Current state and features of financing of the road sector. Scientific bulletin of Polissia. 2017. № 4 (12). P. 201-205.

13. Shkarlet, S. M. Actual problems of formation and funding of the state road funds. Scientific bulletin of Polissia. 2017. № 3(11). P. 16-20.

14. Щодо шляхів розвитку мультимодальних (комбінованих) перевезень в Україні. Аналітична записка. 2011. URL: http://www.niss.gov.ua/articles/599/. 